\title{
WSPÓŁCZESNE KONCEPCJE SPECJALISTYCZNEJ EDUKACJI JĘZYKOWEJ STUDENTÓW PRAWA W POLSCE I W NIEMCZECH W STRONE PROFESJONALIZACJI KSZTALCENIA
}

\begin{abstract}
Streszczenie. Glottodydaktyka europejska i polska podążają za zmieniającą się rzeczywistością kształcenia językowego, na którą wpływ mają propagowane przez Radę Europy i Unię Europejską idee różnojęzyczności i wielojęzyczności. Analiza systemu kształcenia językowego na wydziałach prawa w Polsce i w Niemczech ma na celu poznanie koncepcji kształcenia językowego polskich i niemieckich studentów prawa, szukanie nowatorskich rozwiązań dydaktyczno-metodycznych oraz sposobu wdrażania przez uczelnie standardów europejskich. Wykazanie podobieństw i różnic programowych w zakresie nauczania języków obcych na tle regulacji prawnych, dokonujących się w systemach akademickich, sprzyja wypracowaniu nowych rozwiązań dydaktycznych oraz skłania do głębszej refleksji na sposobami profesjonalnego kształcenia.
\end{abstract}

Słowa kluczowe: konwergencja regulacji prawnych, kształcenie języków obcych na wydziałach prawa, glottodydaktyka, metodyka nauczania.

\section{WSTĘP}

Profesjonalizacja procesu kształcenia językowego w Europie jest ważnym elementem polityki językowej Unii Europejskiej, integracji wiedzy akademickiej, a także zachęca do eksperymentowania w uczeniu się i nauczaniu języków obcych. Przyjrzenie się doświadczeniom edukacji językowej na kierunkach prawniczych wybranych uniwersytetów niemieckich (Uniwersytetu Ludwika Maksymiliana w Monachium, Uniwersytetu Johanna Wolfganga Goethego we Frankfurcie nad Menem i Uniwersytetu w Hamburgu) i porównanie ich z wydziałami prawa trzech polskich uniwersytetów (Uniwersytetu Jagiellońskiego, Uniwersytetu Łódzkiego i Uniwersytetu Wrocławskiego) umożliwi wskazanie podobieństw i różnic w zakresie założeń programowych, treści i koncepcji kształcenia oraz skłoni do głębszej refleksji nad sposobami efektywnego kształcenia studentów prawa. Z uwagi na bliskie sąsiedztwo Polski z Niemcami i współpracę gospodarczą analiza programów kształcenia językowego w Niemczech i w Polsce pozwala poznać aktualne tendencje rozwoju szkolnictwa wyższego w tych krajach, a także przynieść wymierne korzyści dla transferu myśli glottodydaktycznej.

*Uniwersytet Łódzki, Studium Języków Obcych, lbiedron@uni.lodz.pl. 


\section{ZJAWISKO KONWERGENCJI REGULACJI PRAWNYCH W SYSTEMACH AKADEMICKICH. PERSPEKTYWA KSZTALCENIA JEZZYKOWEGO}

Obecne systemy kształcenia prawniczego funkcjonujące w państwach członkowskich Unii Europejskiej różnią się pod wieloma względami, np. liczbą studentów, profesjami prawniczymi, jakością kształcenia. Współczesne trendy rozwojowe w Europie, zmierzające do harmonizacji systemów szkolnictwa wyższego i unifikacji prawa, wymuszają dyskusję na temat przygotowania studentów prawa do przyszłej praktyki zawodowej.

Głębokie przeobrażenia w gospodarce światowej, będące wynikiem liberalizacji stosunków gospodarczych, internacjonalizacji kapitału, rewolucji informatycznej oraz wzrostu znaczenia międzynarodowych korporacji, to tylko nieliczne efekty globalizacji, które mają wpływ na dynamicznie rozwijające się prawo. Granice terytorialne tracą na znaczeniu, nasilają się procesy migracyjne i postępuje integracja państw oraz ludzi na świecie, spowodowana likwidowaniem różnego rodzaju barier. Zdaniem Romana Tokarczyka „Spektakularne odkrycia naukowe i wynalazki techniczne jak np.: radio, telewizja, telefonia, komputery, samochody, samoloty, satelity zrewolucjonizowały szybkość poruszania się ludzi i diametralnie zmieniły ich sposób komunikowania się" (Tokarczyk 2000, 21). Zarówno te zmiany, jak i eksplozja potrzeb ludzkich spowodowały szybki rozwój współczesnego prawa i wymusiły kooperację w wielu jego gałęziach. Pojawienie się zjawiska globalizacji w naukach prawnych spowodowało dyskusję o wzajemnym upodabnianiu się, przenikaniu i dążeniu do zbieżności systemów oraz kultur prawnych. Powszechna europeizacja prawa w ramach Unii Europejskiej prowadzi do usuwania odrębności prawa krajowego, ujednolicania porządków prawnych i wytworzenia rozległej kazuistyki prawnej. Znajomość wyłącznie prawodawstwa krajowego jest niewystarczająca, ponieważ problemy, z jakimi stykają się prawnicy, dotyczą regulacji prawnych niejednokrotnie kilku państw. Trudno też nie zauważyć, że dotychczasowe przepisy ulegają szybkiej dezaktualizacji, a dynamika rozwoju prawa unijnego wobec rosnących potrzeb przekracza wszelkie racjonalne wyobrażenia o ciągle zmieniającym się systemie prawa. Rozwój nowych gałęzi, np. prawa konkurencji Unii Europejskiej, prawa konsumentów, prawa biznesu, wynika z dużej liczby spraw i różnorodnych przypadków, jest konsekwencją wkraczania normowania prawnego we wszystkie sfery życia. Ścieranie się starych i nowych idei normatywnych rzuca niemałe wyzwanie edukacji prawniczej i językowej studentów prawa, którzy nieustannie będą sięgać w pracy zawodowej do dorobku innych krajów. Kształcenie uwarunkowane dotychczas krajowymi rozwiązaniami edukacyjnymi wydaje się być już niewystarczające, a co za tym idzie konieczne jest coraz częstsze sięganie do wzorów obcych. W świetle powyższego należy zastanowić się nad procesem zmierzającym do ukształtowania uniwersalnego systemu edukacji prawniczej 
w Europie, który mógłby się opierać na zbliżonych albo prawie identycznych normach prawnych, egzaminy zdawane na uniwersytetach byłyby wzajemnie uznawane, dyplomy ukończenia studiów w równym stopniu honorowane przez pracodawców, a absolwenci prawa mieliby jednakowe szanse kariery zawodowej we wszystkich krajach europejskich. Wraz z podpisaniem 19 czerwca $1999 \mathrm{r}$. przez 29 ministrów i przedstawicieli szkolnictwa wyższego krajów europejskich Deklaracji bolońskiej i utworzeniem w roku 2010 Europejskiego Obszaru Szkolnictwa Wyższego (European Higher Education Area) rozpoczął się faktyczny proces integracji europejskiej w obszarze szkolnictwa wyższego i konwergencji regulacji prawnych w systemach akademickich, których celem jest wspólne rozwiązywanie problemów akademickich i kształtowanie europejskiego obywatela. $\mathrm{Z}$ tego też względu, według Tokarczyka, znacząca rola w Unii przypada językom. Sporządzanie wielojęzycznych aktów normatywnych, wydawanie decyzji i orzeczeń unijnych wymaga pracy specjalistów z bardzo dobrą znajomością prawa i języków obcych, dlatego w strukturach Unii pracuje około tysiąca specjalistów, którzy dokonują przekładów, aby przygotować tym samym grunt dla europeizacji prawa. Wszelkie regulacje prawne Unii Europejskiej są publikowane w 24 językach w „Official Journal of the European Communities”. Komisja Europejska wspiera inicjatywy mające na celu propagowanie na obszarze Unii ponad 60 języków regionalnych lub języków mniejszości, ponieważ posługuje się nimi około 40 milionów osób. Unia Europejska i Rada Europy pomagają państwom unijnym, poprzez rekomendacje i strategie, realizować narodową politykę językową, która jest spójna w zakresie doboru języków, metod nauczania, zasad kształcenia z europejską polityką edukacji. Wydziały prawa starają się coraz lepiej konstruować programy nauczania, dopasować je do celów, wprowadzać innowacyjne rozwiązania, które zapewnią efektywność procesu kształcenia również w zakresie nauki języka obcego specjalistycznego.

\section{KSZTAŁCENIE JĘZYKOWE PRAWNIKÓW W NIEMCZECH I W POLSCE}

Biegła znajomość języków obcych jest niezbędna przy ubieganiu się o pracę na rynku pozbawionym granic. Uniwersytety odgrywają szczególną rolę w promowaniu wielojęzyczności. Swoją obszerną ofertą kształcenia językowego zachęcają studentów do nauki kilku języków, rozwijania wiedzy specjalistycznej i zdobywania umiejętności interkulturowych. Proces boloński podkreśla znaczenie umiejętności językowych studentów, pracowników naukowych, dydaktycznych oraz administracyjnych dla ich kariery zawodowej. Ważnym narzędziem realizującym jego założenia są Europejskie Ramy Kwalifikacji (ERK z 2008 r.) i Krajowe Ramy Kwalifikacji, które umożliwiają stworzenie wspólnego punktu odniesienia dla systemów edukacyjnych państw członkowskich Unii i zwiększenie przejrzystości kwalifikacji. Niemieckie Ramy Kwalifikacji dla Szkolnictwa 
Wyższego (Qualifikationsrahmen für Deutsche Hochschulabschlüsse) z 2005 r. zostały ponownie opracowane w roku 2017 i służą zwiększeniu przejrzystości kwalifikacji na poziomie ogólnoeuropejskim. Polskie Ramy Kwalifikacji, obowiązujące od 1 października 2012 r., zawierają jednolite i spójne z ERK standardy opisywania kwalifikacji. Stosowanie Europejskich Ram Kwalifikacji jako narzędzia do porównywania poziomów kwalifikacji stwarza równe szanse w społeczeństwie opartym na wiedzy i przyczynia się do integracji europejskiej.

W Niemczech edukacja prawnicza podzielona jest na dwa obszary kształcenia, które uregulowane są w Niemieckiej ustawie o sędziach z dnia 8 września 1961 r. - Deutsches Richtergesetz, zwanej także ustawą federalną ${ }^{1}$. Uwzględniając jej brzmienie, kraje związkowe wydały własne akty prawne, na podstawie których wydziały prawa ustalają szczegółowy program studiów, profil oraz czas ich trwania, który nie może być krótszy niż 3,5 roku. Studia kończą się pierwszym egzaminem państwowym, organizowanym przez ministerstwo sprawiedliwości bądź sąd apelacyjny danego kraju. Zdanie egzaminu nie uprawnia do wykonywania zawodu prawnika, lecz pozwala kontynuować naukę w drugim obszarze, tzn. jest warunkiem dopuszczenia do udziału w kształceniu praktycznym - aplikacji prawniczej nadzorowanej przez sądy okręgowe lub apelacyjne w danym kraju związkowym. W trakcie dwóch lat nauki aplikanci przygotowują się do drugiego egzaminu państwowego, którego zaliczenie uprawnia do otrzymania tytułu Volljurist i umożliwia wpisanie na listę adwokatów, notariuszy czy sprawowanie funkcji sędziego. Profesjonalizacja procesu kształcenia, zorientowanego na przygotowanie zawodowe, uwzględnia odpowiedni program nauczania języka obcego. Uniwersyteckie wydziały prawa, realizując założenia Niemieckiej ustawy o sędziach, paragraf 5a ustęp 2 zdanie 2 (DRiG § 5a Abs. 2 S.2), wprowadzają do swoich programów obligatoryjną naukę 28 godzin lekcyjnych języka specjalistycznego, którego znajomość ma ułatwić komunikację w pracy i środowisku międzynarodowym. Zajęcia o tematyce prawniczej w języku obcym lub kurs językowy o profilu prawniczym organizowane są przez centra języków specjalistycznych, mieszczące się na wydziałach prawa lub współpracujące z tymi wydziałami. Nauczyciele akademiccy - wykładowcy wydziału prawa z tytułem Legum Magister (magister prawa) organizują naukę języka na ćwiczeniach lub wykładach dla studentów ze znajomością języka obcego na poziomie B1, B2 lub C1 według europejskiego systemu opisu kształcenia językowego. W stałej ofercie języków specjalistycznych na uczelniach są zazwyczaj: język angielski, francuski, włoski, hiszpański, turecki, rosyjski, portugalski. Uniwersyteckie wydziały prawa

${ }^{1}$ Deutsches Richtergesetz in der Fassung der Bekanntmachung vom 19. April 1972 (BGBl. I S. 713, das zuletzt durch Artikel 9 des Gesetzes vom 8. Juni 2017 (BGBl. I S. 1570) geändert worden ist (federalna ustawa o sędziach w brzmieniu z 19.04.1972 - Federalny Dziennik Ustaw 1972, cz. I, s. 713, która ostatnio została zmieniona przez art. 9 ustawy z 6.06.2017 r. - Federalny Dziennik Ustaw, cz. I, s. 1570). 
w Hamburgu i we Frakfurcie reagują na potrzeby językowe studentów, którzy zgłaszają chęć poznania prawa polskiego. Celem nauki jest konieczność wymiany doświadczeń i informacji dotyczących obrotu prawnego, przygotowanie zawodowe przyszłych prawników niemieckich do obsługi klientów współpracujących z polskimi firmami. Zorganizowanie zajęć na Uniwersytecie w Monachium z języka chińskiego prawniczego, na których nie wymaga się wcześniejszej znajomości języka, jest podyktowane rosnącym zainteresowaniem prawem chińskim. Warunkiem koniecznym do osiągnięcia sukcesu biznesowego w relacjach niemieckich partnerów handlowych z kontrahentami chińskimi jest poznanie kultury prawnej Chin. Studenci wszystkich wydziałów mają dodatkowe możliwości poszerzenia swoich kompetencji językowych, uczęszczając na kursy z języka ogólnego i specjalistycznego organizowane przez uczelniane centra językowe. Na szczególną uwagę zasługuje oferta przodującego w rankingach niemieckich wydziałów prawa Uniwersytetu Ludwika Maksymiliana (LMU Universität). W trakcie semestru i w czasie wolnym od zajęć Centrum Językowe w Monachium organizuje kursy językowe z ponad 49 języków, w tym chińskiego, hebrajskiego, perskiego, azteckiego. Istotnym faktem jest brak opłat za uczestnictwo w zajęciach. Studenci ponoszą niekiedy koszty kopii materiałów dydaktycznych lub podręczników do nauki.

W Polsce prawo od wielu lat należy do prestiżowych kierunków studiów. Program na studiach prawniczych jest konstruowany w oparciu o ustawę Prawo o szkolnictwie wyższym z dnia 27 lipca 2005 r. i Rozporządzenie Ministra Nauki i Szkolnictwa Wyższego z dnia 2 listopada 2011 r. w sprawie Krajowych Ram Kwalifikacji. Studia na wydziałach prawa w Polsce trwają 10 semestrów i kończą się obroną pracy magisterskiej. Otrzymanie dyplomu uniwersyteckiego i uzyskanie tytułu magistra nie gwarantuje absolwentom przyjęcia na aplikację. By rozpocząć drugi etap kształcenia, są zobowiązani zdać egzamin wstępny przed polskimi izbami adwokackimi. W skład trzyletniego cyklu szkoleniowego przewidzianego programem aplikacji wchodzą zajęcia teoretyczne i praktyczne w sądach, prokuraturach, kancelariach prawnych, urzędach. Ukończenie aplikacji umożliwia przystąpienie do egzaminu zawodowego i nabycie prawa do samodzielnego wykonywania zawodu. Na polskim i światowym rynku usług małe kancelarie bez wyspecjalizowanej praktyki są zastępowane przez duże kancelarie korporacyjne z potencjałem intelektualnym. Prawnicy, by odnieść sukces, muszą wykazać się wiedzą interdyscyplinarną, w tym dobrą znajomością języków obcych i prawa obcego. Współczesny model edukacji uniwersyteckiej na wydziałach prawa w Polsce uwzględnia kształcenie językowe. Ustawowo gwarantuje się studentom prawa na stacjonarnych studiach dziennych 120 godzin lekcyjnych jako minimum programowe, które przez część wydziałów prawa zwiększane jest nawet do 240 godzin, jak w przypadku Uniwersytetu Jagiellońskiego i Wrocławskiego. Studenci prawa, którym uczelnie proponują więcej godzin, mają szansę na wyrównanie poziomu w nauce języka ogólnego. 
W ten sposób stwarza się im korzystniejsze warunki kontynuacji nauki języka, określanego mianem drugiego, którego proces uczenia się przebiegał dotychczas wolniej i bez motywacji. Organizacją obowiązkowego kształcenia językowego na wydziałach prawa w Polsce zajmują się uczelniane centra językowe (np. Jagiellońskie Centrum Językowe) lub studia języków obcych (Studium Języków Obcych Uniwersytetu Łódzkiego, Studium Praktycznej Nauki Języków Obcych na Uniwersytecie Wrocławskim). Powyższe uczelniane jednostki mają duże doświadczenie w kształceniu językowym dorosłych. Zatrudnieni w nich wykładowcy są absolwentami studiów neofilologicznych. W swojej pracy dydaktycznej koncentrują się zazwyczaj na doskonaleniu umiejętności w zakresie języka ogólnego, ponieważ stopień opanowania języka przez absolwentów szkół średnich jest na ogół podstawowy. Ustalenie progu zaliczeniowego z egzaminu maturalnego na poziomie $30 \%$ punktów nie tylko nie stanowi motywacji do rzetelnej nauki języka obcego, lecz jest zderzeniem z rzeczywistością uczelnianą, $\mathrm{tj}$. $\mathrm{z}$ osiągnięciem sześćdziesięcioprocentowego minimum stosowanego przy ocenianiu wiedzy nabytej na ćwiczeniach lub wykładach i pozwalającej uzyskać zaliczenie przedmiotu. Ustalenia dotyczące liczebności grup różnią się na poszczególnych uniwersytetach. Na podstawie wewnętrznych aktów prawnych uczelnie określają minimalną liczebność grupy na około 10 osób, a maksymalną na 30. Do podstawowych języków nauczanych w ramach lektoratu na wydziałach prawa w Polsce należą: język angielski, niemiecki, rosyjski i hiszpański. Ofertą językową wyróżnia się Jagiellońskie Centrum Językowe, które organizuje kształcenie w 13 językach, w tym w japońskim, litewskim, duńskim. Zapisy do grup lektoratowych są dokonywane zgodnie z życzeniami studentów, którzy weryfikują swoje umiejętności językowe rozwiązując test kwalifikujący. Lektoraty rozpoczynają się od poziomu językowego B1, ale na niektórych wydziałach prawa naukę innego języka niż angielski można rozpocząć od poziomu A2 (na Uniwersytecie Łódzkim). Oprócz ustawowo gwarantowanych 120 godzin lektoratu studenci mogą skorzystać z zajęć prowadzonych w myśl koncepcji zintegrowanego kształcenia przedmiotowo-językowego, czyli przedmiotów specjalizacyjnych w formie wykładów, konwersatoriów w języku angielskim, niemieckim, francuskim, hiszpańskim, rosyjskim lub innym. W ramach różnych projektów powstają szkoły prawa obcego dla studentów polskich i szkoły prawa polskiego dla studentów obcojęzycznych.

Autonomia uczelni niemieckich i polskich pozwala na projektowanie własnych programów dostosowanych do potrzeb rynkowych przy jednoczesnym zachowaniu krajowych i europejskich standardów kształcenia dla studiów prawniczych. Zebranie długoletnich doświadczeń niemieckich i polskich ośrodków kształcenia językowego zawodów prawniczych oraz porównanie założeń programowych, treści oraz koncepcji kształcenia może mieć istotne znaczenie dla profesjonalizacji kształcenia zawodów prawniczych, czyli kształcenia zorientowanego na przygotowanie zawodowe. 


\section{ZAŁOŻENIA I KONCEPCJE METOD NAUCZANIA PRZYSZŁYCH PRAWNIKÓW W NIEMCZECH I POLSCE. STUDIUM PORÓWNAWCZE}

Na polskich i niemieckich uczelniach nieustannej modyfikacji ulegają założenia programowe, treści kształcenia i koncepcje metodyczne. W celu poznania tych zmian analizie poddano programy kształcenia na wydziałach prawa trzech niemieckich uniwersytetów: Uniwersytetu Ludwika Maksymiliana w Monachium, Uniwersytetu Johanna Wolfganga Goethego we Frankfurcie nad Menem, Uniwersytetu w Hamburgu i trzech polskich: Uniwersytetu Jagiellońskiego, Uniwersytetu Łódzkiego i Uniwersytetu Wrocławskiego. Zebrane informacje umożliwiają poznanie procesu kształcenia językowego w południowych (Bawaria), środkowych (Hesja) i północnych Niemczech (Hamburg) oraz na prestiżowych wydziałach prawa w Polsce.

\subsection{Założenia metodologiczne studium}

Procesowi reformowania systemów edukacji językowej towarzyszy transfer myśli glottodydaktycznej. Glottodydaktyka europejska i polska podążają za zmieniającą się rzeczywistością kształcenia językowego, na którą wpływ mają propagowane przez Radę Europy idee różnojęzyczności i wielojęzyczności. Zdaniem Przemysława E. Gębala współczesna europejska koncepcja edukacji językowej sugeruje postrzeganie szerokiego kontekstu uczenia się większej liczby języków, a nie traktowanie przyswajania każdego z nich jako oddzielnych elementów, rozwijających się równolegle. Pionierką dociekań w wielojęzycznym kierunku jest w polskiej rzeczywistości glottodydaktycznej Weronika Wilczyńska, która na tym gruncie rozróżnia dwa podejścia badawcze. Pierwsze z nich, zwane bilingwalnym, odpowiada tradycyjnemu sposobowi uprawiania glottodydaktyki. Zgodnie z nim poszczególne glottodydaktyki szczegółowe zorientowane są na nauczanie języków w izolacji od siebie. Drugie podejście, zwane plurilingwalnym, zakłada współpracę pomiędzy poszczególnymi glottodydaktykami szczegółowymi, co z kolei umożliwia nadanie tak realizowanym działaniom badawczym wymiaru komparatystycznego. Plurilingwalne podejście badawcze jest czynnikiem inspirującym dociekania natury porównawczej i pozwala na uwzględnienie dokonań na polu teoretycznym i praktycznym poszczególnych glottodydaktyk szczegółowych, odpowiedzialnych za kształcenie w zakresie kilku języków. W myśl autorskiej koncepcji Gębala analizą porównawczą sposobów organizacji i realizacji elementów kształcenia językowego w ramach różnych systemów edukacyjnych w kontekście ich uwarunkowań natury historycznej, społeczno-ekonomicznej, politycznej oraz kulturowej zajmuje się w wymiarze teoretycznym i empirycznym glottodydaktyka porównawcza - subdyscyplina glottodydaktyki (Gębal 2013, 95).

Francuscy badacze jako pierwsi podjęli merytoryczno-metodologiczną dyskusję na temat glottodydaktyki porównawczej nazwanej didactique comparée des langues-cultures. Prekursorem rozważań na temat glottodydaktycznego nurtu 
komparatystycznego był Christian Puren, który wyodrębnił sześć podejść badawczych w glottodydaktyce: podejście komprehensywne, pragmatyczne, kompleksowe, konstruktywistyczne i jakościowe, oraz pokazal ich wykorzystanie w działalności komparatystycznej. Na gruncie polskim założenia metodologiczne dla glottodydaktyki porównawczej jako interdyscyplinarnej dziedziny badań wyznacza zdaniem Gębala glottodydaktyka ogólna oraz dyscypliny pokrewne, w tym językoznawstwo stosowane i pedagogika.

Współczesna badawcza rzeczywistość glottodydaktyki, także glottodydaktyki specjalistycznej podkreśla wagę dociekań umożliwiających zebranie konkretnych działaniowych potrzeb komunikacyjnych poszczególnych grup użytkowników (Gębal 2016). Czynnikiem sprzyjającym dokonywaniu konfrontacji całych systemów edukacyjnych jest zmieniająca się rzeczywistość, podlegająca globalizacji i europeizacji kształcenia językowego. Dla Louisa Porchera

edukacja porównawcza to sprawa dzisiejszej epoki. Z jednej strony kwestia konstrukcji Europy, [...] przede wszystkim kwestia globalizacji. Edukacja porównawcza to współczesna globalna komunikacja edukacyjna, korespondująca z dzisiejszą rzeczywistością (za Gębal 2013, 69).

Edukacyjne badania porównawcze są ważnym krokiem ku wypracowaniu nowego sposobu postrzegania modelu kształcenia i rozwoju nowych rozwiązań dydaktycznych także na europejskich wydziałach prawa, na które czekają ich studenci, uczący się coraz większej liczby języków.

\subsection{Założenia programowe}

Holistyczne spojrzenie na proces kształcenia prawniczego, konieczność przygotowania zawodowego polskich i niemieckich prawników na intensywną współpracę, wskazanie podobieństw i różnic programowych pozwoli określić realne efekty kształcenia i zmierzyć się z teraźniejszymi oraz przyszłymi wyzwaniami związanymi z realizacją potrzeb praktycznych. Główne założenia programowe kształcenia językowego przyszłych prawników prezentuje Tabela 1.

Tabela 1. Założenia programowe na wybranych niemieckich i polskich wydziałach prawa

\begin{tabular}{|c|c|c|}
\hline $\begin{array}{c}\text { Uniwersytet Ludwika } \\
\text { Maksymiliana w Monachium } \\
\text { Wydzial Prawa (Bawaria) }\end{array}$ & $\begin{array}{l}\text { Uniwersytet Johanna Wolf- } \\
\text { ganga Goethego we Frank- } \\
\text { furcie Wydzial Prawa (Hesja) }\end{array}$ & $\begin{array}{l}\text { Uniwersytet w Hamburgu } \\
\text { Wydzial Prawa } \\
\text { (Hamburg) }\end{array}$ \\
\hline $\begin{array}{l}\mathbf{5} \text { ECTS } \\
\text { - realizacja programu kształce- } \\
\text { nia w oparciu o ustawę fede- } \\
\text { ralną o sędziach Deutsches } \\
\text { Richtergesetz i ustawę krajo- } \\
\text { wą dla Bawarii } \\
\text { - nauka języka obcego specjali- } \\
\text { stycznego }\end{array}$ & $\begin{array}{l}7 \text { ECTS } \\
\text { - realizacja programu kształce- } \\
\text { nia w oparciu o ustawę fede- } \\
\text { ralną o sędziach Deutsches } \\
\text { Richtergesetz i ustawę krajo- } \\
\text { wą dla Hesji } \\
\text { - nauka języka obcego specjali- } \\
\text { stycznego }\end{array}$ & $\begin{array}{l}3 \text { ECTS } \\
\text { - realizacja programu kształce- } \\
\text { nia w oparciu o ustawę fede- } \\
\text { ralną o sędziach Deutsches } \\
\text { Richtergesetz i ustawę krajo- } \\
\text { wą dla Hamburga } \\
\text { - nauka języka obcego specjali- } \\
\text { stycznego }\end{array}$ \\
\hline
\end{tabular}




\begin{tabular}{|c|c|c|}
\hline $\begin{array}{l}\text { - przygotowanie studentów } \\
\text { do komunikacji w środowisku } \\
\text { międzynarodowym } \\
\text { - uzyskanie zaliczenia kursu } \\
\text { językowego uprawniającego } \\
\text { do złożenia pierwszego egza- } \\
\text { minu państwowego (die erste } \\
\text { Juristische Staatsprüfung) }\end{array}$ & $\begin{array}{l}\text { - wprowadzenie do nauki } \\
\text { o różnych systemach prawa } \\
\text { - zdobywanie wiedzy praw- } \\
\text { niczej } \\
\text { - przygotowanie do współpracy } \\
\text { z firmami zagranicznymi } \\
\text { - przedkładanie treści kształce- } \\
\text { nia nad naukę języka } \\
\text { - uzyskanie zaliczenia kursu } \\
\text { językowego uprawniającego } \\
\text { do złożenia pierwszego egza- } \\
\text { minu państwowego (die erste } \\
\text { Juristische Staatsprüfung) }\end{array}$ & $\begin{array}{l}\text { - zdobywanie kluczowych } \\
\text { kwalifikacji (Schlüsselqualifi- } \\
\text { kationen) } \\
\text { - uzyskanie certyfikatu lub } \\
\text { dyplomu z języka obcego } \\
\text { specjalistycznego } \\
\text { - uzyskanie zaliczenia kursu } \\
\text { językowego uprawniającego } \\
\text { do złożenia pierwszego egza- } \\
\text { minu państwowego (die erste } \\
\text { Juristische Staatsprüfung) }\end{array}$ \\
\hline $\begin{array}{c}\text { Uniwersytet Jagielloński } \\
\text { Wydział Prawa } \\
\text { i Administracji }\end{array}$ & $\begin{array}{l}\text { Uniwersytet Łódzki } \\
\text { Wydzial Prawa } \\
\text { i Administracji }\end{array}$ & $\begin{array}{c}\text { Uniwersytet Wroclawski } \\
\text { Wydzial Prawa, } \\
\text { Administracji i Ekonomii }\end{array}$ \\
\hline $\begin{array}{l}8 \text { ECTS } \\
\text { - osiągnięcie poziomu B2+ } \\
\text { - rozwijanie sprawności ję- } \\
\text { zykowych z zakresu języka } \\
\text { ogólnego } \\
\text { - zdobywanie wiedzy o kultu- } \\
\text { rze danego obszaru języko- } \\
\text { wego } \\
\text { - uwrażliwienie studentów } \\
\text { na różnice kulturowe } \\
\text { - wdrożenie do używania języ- } \\
\text { ka w kontekście zawodowym } \\
\text { i akademickim } \\
\text { - przygotowanie do uczest- } \\
\text { nictwa w konwersatoriach } \\
\text { w języku obcym } \\
\text { - rozwijanie kompetencji spo- } \\
\text { łecznych przez współpracę } \\
\text { w grupie }\end{array}$ & $\begin{array}{l}7 \text { ECTS } \\
\text { - osiągnięcie poziomu B2+ } \\
\text { - rozwijanie sprawności z za- } \\
\text { kresu języka specjalistycz- } \\
\text { nego } \\
\text { - zdobywanie wiedzy z zakre- } \\
\text { su gałęzi prawa i systemów } \\
\text { prawnych } \\
\text { - rozbudzenie motywacji } \\
\text { do nauki języka obcego } \\
\text { - wdrożenie do używania języ- } \\
\text { ka w kontekście zawodowym } \\
\text { - doskonalenie technik pracy } \\
\text { z tekstem specjalistycznym } \\
\text { - przygotowanie do uczest- } \\
\text { nictwa w konwersatoriach } \\
\text { w języku obcym } \\
\text { - nauka samodzielnego wy- } \\
\text { rażania opinii na tematy } \\
\text { związane ze środowiskiem } \\
\text { prawniczym, wygłaszanie } \\
\text { prezentacji } \\
\text { - wdrożenie do samokształ- } \\
\text { cenia }\end{array}$ & $\begin{array}{l}\text { 16 ECTS } \\
\text { - osiągnięcie poziomu B2+ } \\
\text { - rozwijanie sprawności z za- } \\
\text { kresu języka ogólnego } \\
\text { - doskonalenie wypowiedzi } \\
\text { na tematy aktualne, abstrak- } \\
\text { cyjne } \\
\text { - umiejętność sporządzenia } \\
\text { notatek z wykładów i pre- } \\
\text { zentacji } \\
\text { - wdrożenie do używania języ- } \\
\text { ka w kontekście zawodowym } \\
\text { - przygotowanie do uczest- } \\
\text { nictwa w konwersatoriach } \\
\text { w języku obcym } \\
\text { - identyfikowanie głównych } \\
\text { myśli w artykułach praso- } \\
\text { wych } \\
\text { - poznanie języka naukowego } \\
\text { stosowanego w referatach, } \\
\text { wykładach, prezentacjach } \\
\text { - wypracowanie własnego stylu } \\
\text { uczenia się }\end{array}$ \\
\hline
\end{tabular}

Źródło: opracowanie własne.

Celem nauki języka specjalistycznego w Niemczech jest realizacja programu kształcenia studentów prawa w oparciu o zasady zawarte w ustawie federalnej i regulaminach lub ustawach krajowych. Kursy przewidziane są dla studentów z dobrą znajomością języka obcego (B1-B2), chociaż ten wymóg nie jest w Niemczech rygorystycznie przestrzegany. Nie ma przymusu pisania 
testu klasyfikującego przed zgłoszeniem się na kurs, gdyż studenci sami oceniają, czy umiejętności językowe pozwolą im na uzyskanie zaliczenia z zajęć specjalistycznych w języku obcym. Zaliczenie kursu o tematyce prawniczej w języku obcym jest warunkiem przystąpienia do pierwszego egzaminu dla prawników i zakończenia uniwersyteckiego etapu kształcenia oraz przykładem na zdobywanie kluczowych kwalifikacji (Schlüsselqualifikationen). Poza tym umożliwia studentom uzyskanie określonej liczby punktów ECTS, np. 7 ECTS przyznaje Wydział Prawa Johanna Wolfganga Goethego, a jedynie 3 ECTS Uniwersytet w Hamburgu. Punkty ECTS odzwierciedlają nakład pracy studenta potrzebny do osiągnięcia założonych w programie efektów kształcenia/ uczenia się. Przyznanie innej liczby punktów ECTS świadczy o różnym oszacowaniu nakładu pracy przeciętnego studenta, jaki przeznaczył na naukę, aby zaliczyć przedmiot. Na zajęciach z języka specjalistycznego przygotowuje się przyszłych prawników do współpracy z firmami zagranicznymi. Zdobywanie wiedzy o różnych gałęziach prawa i systemach prawnych jest głównym założeniem programowym. Ukończenie więcej niż jednego kursu gwarantuje uzyskanie certyfikatu z języka specjalistycznego lub dyplomu i wspiera przygotowanie zawodowe.

Celem obowiązkowej nauki nowożytnego języka obcego w Polsce jest rozwijanie kompetencji komunikacyjnej i osiągnięcie poziomu B2+ zgodnie ze standardami przyjętymi w europejskim systemie opisu kształcenia językowego. Uzyskanie pozytywnej oceny z egzaminu końcowego jest jednym z warunków ukończenia studiów. Podział na grupy lektoratowe odbywa się na podstawie testu kwalifikującego. Większość godzin z 240 na Uniwersytecie Jagiellońskim i Uniwersytecie Wrocławskim poświęcona jest nauce języka ogólnego, około 60 godzin przeznacza się na naukę języka specjalistycznego. Minimum programowe, tj. 120 godzin, na Uniwersytecie Łódzkim, służy kształceniu języka specjalistycznego, przygotowaniu do uczestnictwa w zajęciach przedmiotów prawniczych prowadzonych w językach obcych lub rozpoczęcia studiów w szkole prawa obcego. $\mathrm{Z}$ uwagi na dwukrotnie mniejszą liczbę godzin nauki studenci Uniwersytetu Łódzkiego nie mają możliwości na doskonalenie umiejętności z języka ogólnego. Nauczyciele akademiccy tych trzech uniwersytetów kładą nacisk na rozwijanie umiejętności samokształcenia i samooceny poprzez zlecanie studentom odpowiednich zadań problemowych rozwijających ich sprawności intelektualne, nabycie umiejętności oceny własnych wypowiedzi, sporządzanie notatek z zajęć, przygotowywanie referatów, prezentacji. Stosowane metody nauczania i formy pracy mają za zadanie rozbudzić motywację do nauki języka obcego, co w konsekwencji może zachęcić do wyjazdów w ramach programu Erasmus Plus. Najwięcej punktów ECTS z porównywanych uczelni można uzyskać na Wydziale Prawa, Administracji i Ekonomii Uniwersytetu Wrocławskiego - aż 16 ECTS, a najmniej na Uniwersytecie Łódzkim - 7 ECTS. Zgodnie z przyjętymi w większości krajów 
europejskich standardami oraz obowiązującymi w Polsce regulacjami 1 punkt ECTS odpowiada 25-30 godzinom pracy własnej przeciętnego studenta. Z powyższej punktacji wynika, iż studenci Wydziału Prawa Uniwersytetu Łódzkiego nie tylko mają do dyspozycji najmniej godzin dydaktycznych (120) przeznaczonych na naukę języka z lektorem, lecz także według ECTS poświęcają najmniej godzin na pracę własną (7 x 25-30).

\subsection{Treści kształcenia}

Ważnym elementem kształcenia na wydziałach prawa jest przygotowanie do wykonywania zawodu prawniczego, dlatego model edukacji prawniczej powinien stanowić atrakcyjną i konkurencyjną propozycję dla absolwentów szkół średnich, którzy obecnie mają możliwość zdobywania wykształcenia prawniczego na wielu uczelniach europejskich i amerykańskich. Treści kształcenia, szeroka gama specjalizacji, możliwość poznania prawa nie tylko jednego kraju wpływają na wybór uczelni. Główne treści kształcenia językowego studentów prawa prezentuje Tabela 2.

Tabela 2. Treści kształcenia na wybranych niemieckich i polskich wydziałach prawa

\begin{tabular}{|c|c|c|}
\hline $\begin{array}{c}\text { Uniwersytet Ludwika } \\
\text { Maksymiliana } \\
\text { w Monachium } \\
\text { Wydział Prawa (Bawaria) }\end{array}$ & $\begin{array}{c}\text { Uniwersytet Johanna } \\
\text { Wolfganga Goethego } \\
\text { we Frankfurcie } \\
\text { Wydział Prawa (Hesja) }\end{array}$ & $\begin{array}{c}\text { Uniwersytet w Hamburgu } \\
\text { Wydzial Prawa } \\
\text { (Hamburg) }\end{array}$ \\
\hline $\begin{array}{l}\text { - systemy prawne w krajach } \\
\text { nauczanego języka } \\
\text { - wprowadzenie do termino- } \\
\text { logii prawa, np. amerykań- } \\
\text { skiego, tureckiego } \\
\text { - omówienie aktualnych } \\
\text { problemów prawnych, } \\
\text { np. zgodność homoseksual- } \\
\text { nych związków partnerskich } \\
\text { z konstytucją brazylijską } \\
\text { - charakterystyka różnych } \\
\text { gałęzi prawa } \\
\text { - porównawcze ujęcie zagad- } \\
\text { nień prawnych } \\
\text { - analiza wybranych orzeczeń } \\
\text { sądowych } \\
\text { - nauka sporządzania i reda- } \\
\text { gowania treści umów, doku- } \\
\text { mentów }\end{array}$ & $\begin{array}{l}\text { - nauka o systemach praw- } \\
\text { nych, np. o południowoafry- } \\
\text { kańskim } \\
\text { - struktura sądów, proces two- } \\
\text { rzenia prawa w państwach } \\
\text { europejskich } \\
\text { - interpretacja wydarzeń } \\
\text { bieżących } \\
\text { - omówienie różnych gałęzi } \\
\text { prawa: prawo konstytucyj- } \\
\text { ne, karne } \\
\text { - interpretacja kazusów } \\
\text { z punktu widzenia prawa } \\
\text { porównawczego } \\
\text { - opracowywanie umów, pism } \\
\text { procesowych } \\
\text { - wdrożenie studentów } \\
\text { do naukowych studiów } \\
\text { prawa } \\
\text { - charakterystyka zawodów } \\
\text { prawniczych }\end{array}$ & $\begin{array}{l}\text { - analiza angielskich } \\
\text { zagadnień prawnych: prawo } \\
\text { spółek, prawo własności } \\
\text { intelektualnej, prawo konku- } \\
\text { rencji, prawo negocjacji } \\
\text { - podstawowe zagadnienia } \\
\text { dotyczące migracji } \\
\text { - wpływ europejskich } \\
\text { systemów prawa na prawa } \\
\text { państw pozaeuropejskich, } \\
\text { np. prawo brazylijskie } \\
\text { - zasady i wartości funda- } \\
\text { mentalne prawa człowieka } \\
\text { w państwach o różnych } \\
\text { systemach prawnych } \\
\text { - wpływ zasad religijnych } \\
\text { na międzynarodowe prawo } \\
\text { konwencjonalne } \\
\text { - przygotowanie do studiów } \\
\text { w ramach programu } \\
\text { Erasmus Plus }\end{array}$ \\
\hline
\end{tabular}




\begin{tabular}{|c|c|c|}
\hline $\begin{array}{c}\text { Uniwersytet Jagielloński } \\
\text { Wydział Prawa } \\
\text { i Administracji } \\
\end{array}$ & $\begin{array}{l}\text { Uniwersytet Lódzki } \\
\text { Wydział Prawa } \\
\text { i Administracji }\end{array}$ & $\begin{array}{c}\text { Uniwersytet Wroclawski } \\
\text { Wydzial Prawa, } \\
\text { Administracji i Ekonomii }\end{array}$ \\
\hline $\begin{array}{l}\text { Treści kształcenia: } \\
\text { - zagadnienia tematyczne } \\
\text { - zagadnienia gramatyczno- } \\
\text {-leksykalne } \\
\text { - funkcje językowe } \\
\text { - komponent akademicki } \\
\text { - komponent specjalistyczny }\end{array}$ & $\begin{array}{l}\text { Treści kształcenia: } \\
\text { - zagadnienia tematyczne } \\
\text { - zagadnienia gramatyczno- } \\
\text {-leksykalne }\end{array}$ & $\begin{array}{l}\text { Treści kształcenia: } \\
\text { - zagadnienia tematyczne } \\
\text { - zagadnienia gramatyczne }\end{array}$ \\
\hline $\begin{array}{l}\text { zagadnienia tematyczne } \\
\text { - stereotypy kulturowe } \\
\text { - analiza rynku pracy } \\
\text { - system polityczny } \\
\text { - przestępstwa internetowe }\end{array}$ & $\begin{array}{l}\text { zagadnienia tematyczne } \\
\text { - wprowadzenie do różnych } \\
\text { gałęzi prawa } \\
\text { - systemy sądownictwa } \\
\text { w wybranych krajach } \\
\text { - najważniejsze zagadnienia } \\
\text { z prawa pracy: rozmowa } \\
\text { kwalifikacyjna } \\
\text { - prawo europejskie, } \\
\text { Unia Europejska } \\
\text { - podstawowe pojęcia z prawa } \\
\text { karnego: proces karny } \\
\text { - proces cywilny, wzory umów } \\
\text { - orzeczenia sądowe } \\
\text { - wzory druków, np. policyjnych } \\
\text { - filmy o tematyce prawniczej } \\
\text { (Justiz-Filme) }\end{array}$ & $\begin{array}{l}\text { zagadnienia tematyczne } \\
\text { - zjawisko globalizacji } \\
\text { - przyczyny migracji na świecie } \\
\text { - tolerancja, stereotypy } \\
\text { - emigracja, integracja } \\
\text { w nowym środowisku } \\
\text { - wzrost przestępczości } \\
\text { w krajach europejskich } \\
\text { - praca, aktywność zawodowa, } \\
\text { pracoholizm } \\
\text { - rozmowa kwalifikacyjna } \\
\text { - środki masowego przekazu: } \\
\text { radio, prasa, telewizja, Internet } \\
\text { - system prawny w Polsce } \\
\text { - wybrane elementy z różnych } \\
\text { praw }\end{array}$ \\
\hline $\begin{array}{l}\text { zagadnienia gramatyczno- } \\
\text {-leksykalne, np. } \\
\text { - strona bierna }\end{array}$ & $\begin{array}{l}\text { zagadnienia gramatyczno- } \\
\text {-leksykalne, np. } \\
\text { - strona bierna } \\
\text { - zdania przydawkowe }\end{array}$ & $\begin{array}{l}\text { zagadnienia gramatyczne } \\
\text { - dobór zagadnień jest podpo- } \\
\text { rządkowany tematyce zajęć }\end{array}$ \\
\hline $\begin{array}{l}\text { funkcje językowe } \\
\text { - argumentowanie } \\
\text { - udzielanie rad, wskazówek }\end{array}$ & & \\
\hline $\begin{array}{l}\text { komponent akademicki } \\
\text { - umiejętność robienia notatek } \\
\text { - przygotowanie referatu, } \\
\text { prezentacji }\end{array}$ & & \\
\hline $\begin{array}{l}\text { komponent specjalistyczny } \\
\text { - słownictwo specjalistyczne } \\
\text { Z wybranych gałęzi prawa } \\
\text { - materiały proponowane } \\
\text { przez studentów }\end{array}$ & & \\
\hline
\end{tabular}

Źródło: opracowanie własne. 
W Niemczech w ramach przygotowania do zawodu prawnika wykorzystuje się język obcy do przekazywania treści zintegrowanych z programem kształcenia. Do standardowych tematów należy wprowadzenie do terminologii prawa amerykańskiego, angielskiego, francuskiego, tureckiego itd. Na Uniwersytecie Johanna Wolfganga Goethego we Frankfurcie uwagę przykuwa kurs „Wprowadzenie do prawa południowoafrykańskiego", który jest unikalnym połączeniem systemu prawnego Południowej Afryki z jego korzeniami w prawie romańsko-duńskim i angielskim. Znaczna część programu obowiązkowych zajęć z języka specjalistycznego poświęcona jest różnym systemom prawnym, strukturom sądów, omówieniu poszczególnych gałęzi prawa, analizie orzeczeń sądowych, opracowywaniu dokumentów umów, pism procesowych. Zainteresowaniem cieszy się prawo brazylijskie (w Monachium i Hamburgu) oraz aktualne problemy prawne, np. zgodność z konstytucją homoseksualnych związków partnerskich. Przedmiotem rozważań są także: fundamentalne zasady prawne będące podstawą dla europejskiego prawa dotyczącego uchodźców, analiza krajów migrujących przymusowo lub dobrowolnie w aspekcie rozwiązań humanitarnych, prawo islamskie, wpływ zasad religijnych na międzynarodowe prawo konwencjonalne. Należy zauważyć, iż nie ma tematów tabu, zwłaszcza w Hamburgu. Konieczność sprostania wyzwaniom kształcenia na wydziałach prawa w Niemczech wymaga przygotowania studentów do wyjazdów zagranicznych w ramach programu Erasmus Plus i wdrożenie ich do naukowych studiów.

Na Wydziale Prawa i Administracji Uniwersytetu Jagiellońskiego treści kształcenia podzielone są na zagadnienia tematyczne, gramatyczno-leksykalne, funkcje językowe, komponent akademicki i specjalistyczny. Tematyka z języka ogólnego koncentruje się na aktualnych wydarzeniach społeczno-politycznych, np. problemach migracji, wielokulturowości, analizie rynku pracy, problemie bezrobocia. W późniejszej fazie zajęć lektoratowych studenci poznają terminologię z zakresu prawa cywilnego, karnego, administracyjnego itp. Celem nauczania struktur leksykalno-gramatycznych, funkcji językowych oraz komponentu akademickiego jest przygotowanie studentów do wystąpień w środowisku akademickim oraz nabycie umiejętności kontaktowania się z zagraniczną kadrą naukową. Podobne podejście w zakresie doboru treści kształcenia istnieje na Wydziale Prawa, Administracji i Ekonomii Uniwersytetu Wrocławskiego. Tematy realizowane na ćwiczeniach dotyczą globalizacji, tolerancji wobec różnorodności kulturowej, aktywności zawodowej, zjawiska migracji na świecie. Około 60 godzin przeznaczono na elementy prawa karnego, prawa cywilnego, prawa pracy, prawa międzynarodowego oraz system prawny w Polsce. Na Wydziale Prawa i Administracji Uniwersytetu Łódzkiego 120 godzin poświęca się na nauczanie języka specjalistycznego. Wybierane tematy dotyczą systemów sądownictwa w kraju nauczanego języka obcego, struktur organów państwowych, elementów prawa konstytucyjnego, administracyjnego, europejskiego czy międzynarodowego publicznego. Studenci analizują fragmenty konstytucji, ustaw, wyroków sądowych, 
poznają wzory umów np. umowę sprzedaży, umowę o pracę oraz druki policyjne, podatkowe. Dobór zagadnień leksykalno-gramatycznych uzależniony jest od treści nauczania.

\subsection{Koncepcje kształcenia}

W procesie kształcenia bez wątpienia istotną rolę odgrywa wybór metody nauczania, materiałów dydaktycznych, technik pracy. Nowe wyzwania stawiane absolwentom wydziałów prawa zwielokrotniły potrzeby studiujących prawo i określiły cel nauczania. Dobór metody powinien wspierać proces dydaktyczny i uatrakcyjniać zajęcia, które z kolei motywują studentów do działania, twórczego myślenia i kreatywnego rozwiązywania problemów. Tabela 3 prezentuje koncepcje kształcenia językowego studentów prawa.

Tabela 3. Koncepcje kształcenia na wybranych niemieckich i polskich wydziałach prawa

\begin{tabular}{|c|c|c|}
\hline $\begin{array}{c}\text { Uniwersytet Ludwika } \\
\text { Maksymiliana } \\
\text { w Monachium } \\
\text { Wydział Prawa (Bawaria) }\end{array}$ & $\begin{array}{c}\text { Uniwersytet Johanna } \\
\text { Wolfganga Goethego } \\
\text { we Frankfurcie } \\
\text { Wydzial Prawa (Hesja) }\end{array}$ & $\begin{array}{c}\text { Uniwersytet w Hamburgu } \\
\text { Wydzial Prawa } \\
\text { (Hamburg) }\end{array}$ \\
\hline $\begin{array}{l}\text { - metoda eklektyczna } \\
\text { - podejście leksykalne } \\
\text { - metoda komunikacyjna } \\
\text { - podejście zadaniowe } \\
\text { - metoda analizy przypadku } \\
\text { (Case Study Method) } \\
\text { - Content and Language } \\
\text { Integrated Learning (CLIL) }\end{array}$ & $\begin{array}{l}\text { - tradycyjne metody } \\
\text { nauczania } \\
\text { - metoda komunikacyjna } \\
\text { - podejście zadaniowe } \\
\text { - metoda analizy przypadku } \\
\text { (Case Study Method) } \\
\text { - Content and Language } \\
\text { Integrated Learning (CLIL) } \\
\text { - metoda sokratyczna }\end{array}$ & $\begin{array}{l}\text { - metoda komunikacyjna } \\
\text { - podejście zadaniowe } \\
\text { - metoda analizy przypadku } \\
\text { (Case Study Method) } \\
\text { - Content and Language } \\
\text { Integrated Learning (CLIL) } \\
\text { - Social Sculpture } \\
\text { Methodology } \\
\text { - metoda symulacyjna } \\
\text { - interaktywne metody }\end{array}$ \\
\hline $\begin{array}{c}\text { Uniwersytet Jagielloński } \\
\text { Wydział Prawa } \\
\text { i Administracji }\end{array}$ & $\begin{array}{l}\text { Uniwersytet Lódzki } \\
\text { Wydzial Prawa } \\
\text { i Administracji }\end{array}$ & $\begin{array}{c}\text { Uniwersytet Wroclawski } \\
\text { Wydzial Prawa, } \\
\text { Administracji i Ekonomii }\end{array}$ \\
\hline $\begin{array}{l}\text { - eklektyzm } \\
\text { - metoda komunikacyjna } \\
\text { - podejście zadaniowe } \\
\text { - metoda analizy przypadku } \\
\text { (Case Study Method) } \\
\text { - metody podające: referat, } \\
\text { prezentacja multimedialna }\end{array}$ & $\begin{array}{l}\text { - współczesny eklektyzm } \\
\text { glottodydaktyczny } \\
\text { - metoda komunikacyjna } \\
\text { - podejście zadaniowe } \\
\text { - zintegrowane kształcenie } \\
\text { przedmiotowo-językowe } \\
\text { (CLIL) } \\
\text { - metoda analizy przypadku } \\
\text { (Case Study Method) } \\
\text { - metody multimedialne }\end{array}$ & $\begin{array}{l}\text { - metoda komunikacyjna } \\
\text { - podejście zadaniowe } \\
\text { - zintegrowane kształcenie } \\
\text { przedmiotowo-językowe } \\
\text { (CLIL) }\end{array}$ \\
\hline
\end{tabular}

Źródło: opracowanie własne. 
W Niemczech wykorzystuje się zarówno tradycyjne metody nauczania skoncentrowane na przekazywaniu wiedzy, jak i nowoczesne, skoncentrowane na treningu strategii uczenia się. Podejście leksykalne ułatwia czytanie ze zrozumieniem treści ustaw, rozporządzeń, analizę dokumentów prawnych i używanie w różnych kontekstach terminów prawnych. Podejście zadaniowe pozwoli studentom rozwiązywać w parach lub kilkuosobowych grupach zadania złożone i wieloetapowe. Analizując oryginalne umowy, pisma procesowe, wyroki, studenci uczą się współpracy i współdziałania w zespołach, poznają konkretną argumentację, a także sposoby negocjacji. Wykorzystywana w dydaktyce metoda studium przypadku (Case Study Method) pozwala, zdaniem Wojciecha Grzegorczyka, szczegółowo zobrazować zazwyczaj rzeczywiste zjawisko, przypadek w celu sformułowania wniosków o przyczynach i rezultatach jego przebiegu (Grzegorczyk 2015). Typami przypadków w prawie mogą być zeznania świadków, relacje osób będących świadkami jakiegoś zdarzenia, dokumentacja sądowa. Analiza pisemnego wyroku sądowego i dokumentacji umożliwia zrozumienie zachodzących procesów i stanowi idealny materiał naukowy, który można wykorzystać w celach edukacyjnych. Metoda ta jest charakterystyczna dla sądownictwa Stanów Zjednoczonych i Wielkiej Brytanii, w których prawo oparte jest na precedensach stanowiących wykładnie innych wyroków w podobnych sprawach. Metodą rekomendowaną przez Komisję Europejską jest zintegrowane kształcenie przedmiotowo-językowe (Content and Language Integrated Learning - CLIL) ${ }^{2}$. Różni się od tradycyjnej lekcji językowej aspektem przekazywania przede wszystkim wiedzy przedmiotowej, a nie koncentrowaniem uwagi na poprawności użycia języka. Język obcy jest narzędziem motywującym do rozwijania kompetencji zawodowych, a nie celem samym w sobie. O refleksyjności w procesie edukacji przyszłych prawników w Niemczech świadczą: metoda sokratyczna i metoda rzeźby społecznej (Social Sculpture Methodology). Metoda sokratyczna używana jest w większości amerykańskich szkół prawniczych. Nauczyciel, wzorując się na Sokratesie, zadaje w sposób przemyślany studentom szereg sterowanych pytań. Odpowiedzi na nie tworzą logiczny ciąg, do którego zmierza uczeń, nie wiedząc o tym wcześniej. Social Sculpture Methodology to metoda stymulowania kreatywności poprzez interdyscyplinarny dialog. Przykładem nieszablonowego spojrzenia w podejściu do rozwiązywania problemów są wykłady i ćwiczenia interaktywne. Dzięki inscenizacjom z odgrywaniem ról przed sądem, doradzaniem klientom pobudzają do myślenia, uczą kreatywności i są efektem łączenia teorii z praktyką.

W Polsce coraz częściej odchodzi się od uczenia kodeksu na pamięć na rzecz ćwiczenia prawdziwego rzemiosła, tj. analizy dokumentów prawniczych i umiejętności praktycznych. Popularny eklektyzm łączy elementy starych i aktualnych

${ }^{2}$ Szerzej zob. Uchwała Rady z dnia 31 marca 1995 r. w sprawie podniesienia poziomu i zróżnicowania form uczenia się i nauczania języków obcych w systemach edukacji Unii Europejskiej, Dz.Urz. UE C 207 z 12 sierpnia 1995 r. 
metod nauczania, których różnorodność podyktowana jest programem nauczania, treściami kształcenia, podejściem do nauczania języka ogólnego i specjalistycznego. Wymiana poglądów, dyskusje na temat aktualnych wydarzeń współczesnego świata sprzyjają stosowaniu metody komunikacyjnej. Stawianie przed studentami nowych wyzwań, kształcenie umiejętności działania i współpracy w języku obcym w różnych dziedzinach życia społecznego umożliwia podejście zadaniowe, które „nie zmienia lub zmienia w niewielkim stopniu głównych założeń metod komunikacyjnych, jest ich udoskonaloną wersją" (Janowska 2011, 87). Studenci uczą się działania w różnych kontekstach życia społecznego. Zadania są zamierzonymi działaniami, podejmowanymi przez uczących się w celu rozwiązania problemu (Janowska 2011, 82). Wśród metod stosowanych na Uniwersytetach Jagiellońskim i Łódzkim wymienia się studium przypadku (Case Study). Jest to sposób na ukazanie cech charakterystycznych danego procesu, pojawiających się trudności i przyczyny, będącej motorem na drodze do sukcesu. „Innymi słowy - case study pozwala nam uczyć się na cudzych błędach, ale również i na cudzych sukcesach" (Dańda, Lubecka 2010, 3). Zintegrowane kształcenie przedmiotowo-językowe (Content and Language Integrated Learning - CLIL) pozwala studentom pozyskiwać merytoryczne informacje z poszczególnych gałęzi prawa dzięki umiejętnościom językowym. Sposób uczenia języka przez poznawanie wyspecjalizowanych treści odróżnia tę metodę od tradycyjnego podejścia do nauczania. Metody multimedialne umożliwiają wizualizację materiału nauczania i wspomagają zrozumienie niektórych treści kształcenia, pomagają monitorować proces dydaktyczny. Różnorodność stosowanych metod świadczy o tym, że nauczyciele akademiccy starają się sprostać wymogom współczesnej edukacji.

\subsection{Wnioski z analiz porównawezych}

System kształcenia prawników ulega ustawicznym przemianom, mającym na celu dostosowanie do potrzeb edukacyjnych prawników tak, aby mogli oni odpowiednio reagować na problemy różnych grup społecznych i wymogi rynku. Te zmiany są widoczne w nauczaniu języków obcych, których celem jest wsparcie kształcenia zawodowego na wydziałach prawa, wdrożenie do działania społecznego, przygotowanie do podjęcia pracy zawodowej w kraju i za granicą.

Założenia programowe: Polski system kształcenia językowego skoncentrowany jest na nauce języka obcego w celu osiągnięcia poziomu B2+. W Niemczech kładzie się nacisk na zdobywanie wiedzy o systemach prawnych dzięki nauce języka. Gwarantowana liczba 28 godzin na niemieckich wydziałach prawa jest prawie czterokrotnie mniejsza od obligatoryjnych 120 na polskich, mimo to system niemiecki lepiej reaguje na potrzeby zawodowe przyszłych prawników.

Treści kształcenia: W Niemczech treści kształcenia w języku obcym dotyczą wyłącznie problematyki prawnej. Uniwersytety odgrywają ważną rolę w przełamywaniu barier i uprzedzeń etnicznych. Na uwagę zasługuje zainteresowanie 
nie tylko europejskimi systemami prawnymi (prawem południowoafrykańskim, brazylijskim). W Polsce na Uniwersytecie Jagiellońskim i Wrocławskim dominują tematy z języka ogólnego, na Uniwersytecie Łódzkim z języka specjalistycznego. W Niemczech kształcenie odbywa się w różnych językach, w Polsce większość studentów decyduje się na kontynuację nauki języka angielskiego.

Koncepcja kształcenia: W nauczaniu języków obcych w obu krajach wykorzystuje się zarówno metody klasyczne, jak i współczesne, skoncentrowane na osobie uczącej się i jej potrzebach. Wybór metody nauczania podyktowany jest tematem zajęć i formą jego realizacji. Niemiecki system wykazuje większą refleksyjność w ocenie procesu kształcenia, poszukując coraz nowszych koncepcji metodycznych. Porównywanie polskiego i niemieckiego systemu edukacji językowej studentów prawa jest konsekwencją europeizacji i standaryzacji kształcenia językowego. Zaobserwowane tendencje są motorem zbierania doświadczeń i rozwiązań, które pozwolą uwzględnić w projektowanych programach realne potrzeby komunikacyjne i działaniowe przyszłych prawników, wynikające z realizacji zadań zawodowych.

\section{PODSUMOWANIE}

Niemiecki system kształcenia skoncentrowany jest przede wszystkim na przygotowaniu studentów do wykonywania zawodu prawniczego. Zdobywanie wiedzy o innych systemach prawnych, nie tylko europejskich, chęć przygotowania do komunikacji specjalistycznej, odgrywanie ról przed sądem, rozwiązywanie kazusów na kursach językowych to przykłady łączenia elementów kształcenia teoretycznego z praktyką. Zgodnie z regulaminami studiów, które przewidują obowiązek przyswojenia terminologii prawniczej z jednego wybranego języka obcego, niemieckie wydziały prawa przedstawiają szeroką ofertę nauki jezyków specjalistycznych. Studenci mają możliwość uczestniczenia nawet w kursach językowych dla początkujących, jeśli istnieje zainteresowanie danymi systemami prawnymi. Na wydziałach prawa w Polsce studenci uczą się najpierw języka ogólnego, a następnie terminologii prawniczej. Powodem dominacji języka angielskiego jest niedostateczna znajomość drugiego języka i obawa przed brakiem uzyskania z niego zaliczenia. Fakt ten uniemożliwia poznanie innych języków i systemów prawnych w tych językach, co w konsekwencji może utrudnić proces profesjonalizacji kształcenia prawników w Polsce. 


\section{BIBLIOGRAFIA}

Antonelli, Gulia. 2017. „Brauchen Juristen Fremdsprachenkenntnisse?”. Beck-stellenmarkt.de 15. https://www.beck-stellenmarkt.de/ratgeber/karriere/ratgeber-karriere/brauchen-juristen-fremdsprachenkenntnisse [dostęp 2.01.2018].

Bosiacki, Adam. 2014. „Konwergencja systemów prawnych w okresie globalizacji: spostrzeżenia i możliwe perspektywy". W Tendencje rozwojowe myśli politycznej i prawnej. Red. Marek Maciejewski, Maciej Marszał, Mirosław Sadowski. 279-287. Wrocław: Wydział Prawa i Ekonomii Uniwersytetu Wrocławskiego.

Chmielecka, Ewa. 2013. „Proces boloński i krajowe ramy kwalifikacji dla szkolnictwa wyższego”. Studia BAS 3 (35): 107-134.

Cybulska, Katarzyna. 2009. „Różnojęzyczność a kształcenie językowe w szkolnictwie wyższym”. W Kształcenie językowe w szkolnictwie wyższym. Red. Hanna Komorowska. 97-113. Warszawa: Wydawnictwo Szkoły Wyższej Psychologii Społecznej Academica.

Dańda, Aleksander, Joanna Lubecka. 2010. Casebook. Metodologia tworzenia case study. Kraków. https://ekonomia.zut.edu.pl/fileadmin/pliki/users/264/Konkurs_ekon_dla_uczniow/caseBOOK___metodologia.pdf [dostęp 2.08.2018].

Gajewska-Skrzypczak, Iwona, Barbara Sawicka. 2017. „Język specjalistyczny na uczelni technicznej. Refleksje nauczycieli praktyków”. Języki Obce w Szkole 3: 52-57.

Gębal, Przemysław E. 2013. Modele ksztatcenia nauczycieli języków obcych w Polsce $i$ w Niemczech. W stronę glottodydaktyki porównawczej. Kraków: Księgarnia Akademicka.

Gębal, Przemysław E. 2016. „Od dydaktyki tekstów specjalistycznych do dydaktyzacji potrzeb i działań komunikacyjnych. Kierunki i koncepcje glottodydaktyki specjalistycznej”. Acta Universitatis Lodziensis. Ksztatcenie Polonistyczne Cudzoziemców 23: 19-33.

Grucza, Franciszek. 1978. „Glottodydaktyka, jej zakres i problemy”. Przeglad Glottodydaktyczny 1: $3-35$.

Grzegorczyk, Wojciech. 2015. „Studium przypadku jako metoda badawcza i dydaktyczna w naukach o zarządzaniu". W Wybrane problemy zarzadzania i finansów. Studia przypadków. Red. Wojciech Grzegorczyk. 9-16. Łódź: Wydawnictwo Uniwersytetu Łódzkiego.

Harbig, Anna Maria. 2007. „Nauczanie języków obcych w aspekcie przemian w polskim szkolnictwie wyższym”. W IV Międzynarodowa Konferencja Edukacyjna - Ustroń 2017 „Przez języki do sukcesu” [referaty]. 64-70. http://kms.polsl.pl/prv/spnjo1/referaty/harbig.pdf [dostęp 20.12.2017].

Janowska, Iwona. 2011. Podejście zadaniowe do nauczania i uczenia się języków obcych. Na przykładzie języka polskiego jako obcego. Kraków: Universitatis.

Kubiak, Bogusław. 2002. „Pojęcie języka specjalistycznego”. Języki Obce w Szkole 5: 6-11.

Mirowska-Łoskot, Urszula. 2015. „Jak uczyć prawników, czyli co zrobić, żeby elita nie pracowała w supermarkecie". Gazeta Prawna.pl. http://prawo.gazetaprawna.pl/artykuly/884609,jak-uczyc-prawnikow-czyli-co-zrobic-zeby-elita-nie-pracowala-wsupermarkecie.html,komentarze-najnowsze [dostęp 24.07.2015].

Pankowska-Lier, Beata. 2017. „Wykształcenie prawnicze w Niemczech”. Studia Iuridica Lublinensia 26 (4): 43-47.

Pietraś, Marek. 2017. „Umiędzynarodowienie szkolnictwa wyższego w Polsce”. W Internacjonalizacja polskich ośrodków politologicznych. Red. Tomasz Domański, Alicja Stępień-Kuczyńska, Agata Włodarska-Frykowska. 81-95. Łódź: Wydawnictwo Uniwersytetu Łódzkiego.

Sobański, Remigiusz. 1998. „Kultura prawna Europy”. Studia Europejskie 3: 117-129.

Tokarczyk, Roman. 2000. „Kultura prawa europejskiego”. Studia Europejskie 1: 11-26. 
Tokarczyk, Roman. 2012. Tworzenie prawa. Pomiędzy kultura prawa stanowionego i kulturą common law". W Konwergencja czy dywergencja kultur i systemów prawnych. Red. Oktawian Nawrot, Sebastian Sykuna, Jerzy Zajadło. 3-24. Warszawa: Wydawnictwo C.H. Beck.

Urbanikowa, Jolanta. 2001. „Europejski Rok Języków. Proces boloński i polityka językowa w Uniwersytecie Warszawskim". Nauka i Szkolnictwo Wyższe 2 (18): 123-131.

Wesołowska, Anna. 2013. „Proces Boloński i powstanie Europejskiego Obszaru Szkolnictwa Wyższego". Rocznik Integracji Europejskiej 7: 379-388.

Wójcik-Augustyniak, Marzena. 2017. Koncepcja innowacji wartości ustugi edukacyjnej publicznej szkoły wyższej w Polsce. Warszawa: Wydawnictwo Naukowe PWN.

Żygulski, Kazimierz. 2000. „Globalizacja procesów społeczno-gospodarczych”. W Międzynarodowe stosunki gospodarcze. Red. Wiesław Iskra. 28-57. Warszawa: Innowacja, Wyższa Szkoła Społeczno-Ekonomiczna.

\section{Akty prawne}

Ausbildungs - und Prüfungsordnung für Juristen (JAPO) vom 13. Oktober 2003. Regulamin kształcenia i egzaminowania dla prawników z 13 października 2003 w Bawarii. https://www.justiz.bayern.de/media/pdf/ljpa/japo/japo-konsolidierte_fassung_juris_2018-03-01.pdf [dostęp 6.11.2018].

Detailed work programme on the follow-up of the objectives of Education and training systems in Europe (Dz.Urz. UE C 142 z 14 czerwca 2002 r.).

Deutsches Richtergesetz vom 8.09.1961 in der Fassung der Bekanntmachung vom 19. April 1972, das zuletzt durch Artikel 9 des Gesetzes vom 8. Juni 2017 (BGB1. I S. 1570) geändert worden ist. Niemiecka ustawa o sędziach. https://www.gesetze-im-internet.de/drig/DRiG.pdf [dostęp 6.11.2018].

Gesetz über die juristische Ausbildung (Juristenausbildungsgesetz - JAG) vom 8. März 2004. Ustawa o kształceniu zawodów prawniczych w Hesji z dnia 8 marca 2004. http://www.lexsoft.de/ cgi-bin/lexsoft/justizportal_nrw.cgi?xid=169594,1 [dostęp 6.11.2018].

Hamburgisches Juristenausbildungsgesetz (HmbJAG) vom 11. Juni 2003. Ustawa o kształceniu zawodów prawniczych w Hamburgu (HmbJAG) z dnia 11 czerwca 2003 r. http://justiz.hamburg. de/contentblob/1585986/a8b449b183a9401efb72c3f5267e95dc/data/hamburgisches-juristenausbildungsgesetz.pdf [dostęp 6.11.2018].

Rozporządzenie Ministra Nauki i Szkolnictwa Wyższego z dnia 2 listopada 2011 r. w sprawie Krajowych Ram Kwalifikacji dla Szkolnictwa Wyższego (Dz.U. z 2011 r. Nr 253, poz. 1520).

Rozporządzenie Parlamentu Europejskiego i Rady (UE) nr 1288/2013 z dnia 11 grudnia 2013 r. ustanawiające „Erasmus+” - unijny program na rzecz kształcenia, szkolenia, młodzieży i sportu.

Rozporządzenie Rady nr 1 z dnia 15 kwietnia 1958 r. w sprawie określenia systemu językowego Europejskiej Wspólnoty Gospodarczej (Dz.Urz. WE 17 z 6 października 1958 r.).

Uchwała nr 86/V/2014 Senatu Uniwersytetu Jagiellońskiego z dnia 28 maja 2014 r. w sprawie: zmiany uchwały nr 2/I/2012 Senatu Uniwersytetu Jagiellońskiego z dnia 25 stycznia 2012 r. w sprawie wytycznych dla rad podstawowych jednostek organizacyjnych Uniwersytetu Jagiellońskiego w zakresie projektowania programów kształcenia dla studiów pierwszego oraz drugiego stopnia, jednolitych studiów magisterskich, studiów podyplomowych oraz kursów dokształcających.

Uchwała Rady z dnia 31 marca 1995 r. w sprawie podniesienia poziomu i zróżnicowania form uczenia się i nauczania języków obcych w systemach edukacji Unii Europejskiej (Dz.Urz. UE C 207 z 12 sierpnia 1995 r.). 
Uchwała Senatu UŁ nr 458 z dnia 2 kwietnia 2012 r. wraz z jej zmianą - uchwałą nr 247 Senatu Uniwersytetu Łódzkiego z 9 grudnia 2013 r. w sprawie zasad osiągania przez studentów Uniwersytetu Łódzkiego efektów kształcenia w zakresie znajomości i umiejętności posługiwania się nowożytnym językiem obcym.

Ustawa z dnia 27 lipca 2005 r. Prawo o szkolnictwie wyższym (Dz.U. z 2005 r. Nr 164, poz. 1365).

Zarządzenie nr 54/2013 Rektora Uniwersytetu Wrocławskiego z dnia 15 kwietnia 2013 r. w sprawie wprowadzenia Regulaminu Organizacyjnego Studium Praktycznej Nauki Języków Obcych Uniwersytetu Wrocławskiego.

Zarządzenie nr 117/2017 Rektora Uniwersytetu Wrocławskiego z dnia 26 października 2017 r. wprowadzające Zasady nauczania języków obcych i rozliczania studentów z lektoratów w Studium Praktycznej Nauki Języków Obcych Uniwersytetu Wrocławskiego.

\section{Źródla internetowe}

Erasmus +. Przewodnik po programie. Wersja 2 (2017) z 20.01.2017. http://ec.europa.eu/programmes/erasmus-plus/sites/erasmusplus/files/files/resources/erasmus-plus-programme-guide_ pl.pdf [dostęp 14.01.2017].

http://erasmusplus.org.pl/30lat/ [dostęp 2.01.2018].

http://eur-lex.europa.eu/legal-content/NL/TXT/?uri=CELEX:52003DC0685 [dostęp 2.01.2018].

http://eur-lex.europa.eu/legal-content/PL/TXT/?uri=celex\%3A32006H0962 [dostęp 2.01.2018].

http://www.jcj.uj.edu.pl/jcj/kierownicy-zespolow-jezykowych [dostęp 2.01.2018].

http://www.jcj.uj.edu.pl/studenci/programy-nauczania [dostęp 2.01.2018].

http://www.jura.uni-muenchen.de/fakultaet/fachsprachenzentrum/ffa.html [dostęp 2.01.2018].

http://www.jura.uni-muenchen.de/fakultaet/fachsprachenzentrum/info/index.html [dostęp 2.01.2018].

http://www.jura.uni-muenchen.de/fakultaet/fachsprachenzentrum/pflichtkurse/index.html [dostęp 2.01.2018].

http://www.kwalifikacje.edu.pl/pl/strona-glowna/78-zintegrowany-system-kwalifikacji/1003-krk-w-szkolach-wyzszych [dostęp 2.01.2018].

http://www.perspektywy.pl/portal/index.php?option=com_content\&view=article\&id=559:u-multirank-wystartowal\&catid=24\&Itemid=119 [dostęp 15.08.2017].

http://www.wos.net.pl/liceum/globalizacja.html [dostęp 2.01.2018].

https://qis.server.unifrankfurt.de/qisserver/rds;jsessionid=36D82738F177303DF7FE1E59AA 2FD030. waldmarie12? state $=$ wtree $\&$ search $=1 \&$ trex $=$ step $\&$ root $120172=57008 \mid 59353 \& \mathrm{P}$. $\mathrm{vx}=\mathrm{kurz}$ [dostęp 2.01.2018].

https://qis.server.unifrankfurt.de/qisserver/rds?state=verpublish\&status=init\&vmfile=no\&publishi $\mathrm{d}=231389 \&$ moduleCall=webInfo\&publishConfFile=webInfo\&publishSubDir=veranstaltung [dostęp 2.01.2018].

https://www.jura.uni-frankfurt.de/43078948/4fremdsprachige-Rechtskenntnisse3 [dostęp 2.01.2018]. https://www.jura.uni-frankfurt.de/43315839/42Lehrbeauftragte [dostęp 2.01.2018].

https://www.jura.uni-hamburg.de/de.html [dostęp 2.01.2018].

https://www.jura.uni-hamburg.de/studium/lehrveranstaltungen/fremdsprachenangebote.html [dostęp 2.01.2018].

https://www.jura.unihamburg.de/studium/lehrveranstaltungen/fremdsprachenangebote/fachsprachenzentrum.html [dostęp 2.01.2018].

https://www.jura.unihamburg.de/studium/lehrveranstaltungen/fremdsprachenangebote/veranstaltung.html [dostęp 2.01.2018].

https://www.mimuw.edu.pl/ sjack/usw/strat_pliki/strategia.htm [dostęp 2.01.2018].

https://www.usosweb.uj.edu.pl/kontroler.php?_action=katalog2/przedmioty/pokazPrzedmiot\&prz kod=WPA-10.PZ-AB2\%2B [dostęp 2.01.2018]. 
Misja, wizja i cele strategiczne szkolnictwa wyższego w Polsce w perspektywie 2020 roku. Raport czastkowy przygotowany przez konsorcjum Ernst \& Young Business Advisory. Instytut Badań nad Gospodarka Rynkowa. Listopad 2009. https://www.nauka.gov.p1/g2/oryginal/2013_05/9b 9413575c0e968c236bbd1d1f0a64db.pdf [dostęp 20.12.2017].

Strategia rozwoju szkolnictwa wyższego w Polsce do 2020 roku-drugi wariant. Raport czastkowy przygotowany przez konsorcjum Ernst \& Young Business Advisory. Instytut Badań nad Gospodarka Rynkowa. Marzec 2010. https://www.nauka.gov.pl/g2/oryginal/2013_05/59579f9e6efae c82014d6d5be081ca23.pdf [dostęp 20.12.2017].

The Magna Charta Universitatum. http:// www.magna-charta.org/magna-charta-universitatum/the-magna-charta-1/the-magna-charta [dostęp 25.07.2016].

\title{
Lena Biedroń
}

\section{CONTEMPORARY CONCEPTS OF SPECIALIST LANGUAGE EDUCATION OF LAW STUDENTS IN POLAND AND GERMANY TOWARDS THE PROFESSIONALIZATION OF EDUCATION}

\begin{abstract}
The European and Polish glottodidactics follow the changing reality of language education, which is influenced by the Council of Europe and the European Union's promotion of plurilingualism and multilingualism. The analysis of the language education system at the law faculties in Poland and Germany aims at recognising the concept of language education of Polish and German law students, looking for innovative didactic and methodological solutions and for the way of implementing European standards by universities. Demonstration of curriculum similarities and differences in the field of teaching a foreign language against the background of legal regulations in the academic systems favours the development of new didactic solutions and encourages deeper reflection on the methods of professional education.
\end{abstract}

Keywords: convergence of legal regulations, foreign language education in law faculties, glottodidactics, teaching methodology. 